\author{
A.N. Bekmasheva*, M.K. Azhgaliev \\ West Kazakhstan Innovation and Technological University, Kazakhstan \\ (E-mail:vipbekmasheva@mail.ru,Marat_ajigaliev@mail.ru)
}

\title{
Reading as a kind of oral activity in professional language training
}

\begin{abstract}
The article analyzes the topical questions of professional language training. Particular attention is paid to teaching of the reading skills as a type of oral activity. The article considers the problems of teaching different types of reading, taking into account the differences in language training level of students. Reading is considered to be anoral activity that contributes to the development of skills and abilities of oral communication. Itis also characterized as a teaching tool in terms of the content, basic principles of teaching, as well as the sequence of teaching. The authors, based on the classifications of reading types suggested by most scientists, offer their own types of tasks and ways of forming speech competence based on teaching professional reading. The ways of overcoming the difficulties of a foreign language text are proposed. The article also outlines the basic principles of teaching various types of reading.
\end{abstract}

Keywords: reading, oral activity, professional language training, types of reading, authentic text.

\section{Introduction}

Language training is of particular importance in the educational programs of universities in the Republic of Kazakhstan. The task of forming high competitiveness of university graduates dictates the need for trilingualism in our country. Speaking three languages is of high practical importance for successful competition in the labor market, moreover it is an urgent need to obtain both professional and general information, and it is regarded as an important component of the reputation. In this regard, the formation of verbal communication skills on professional topics and conducting scientific discussions is crucial. In professional language training, reading plays a special role. Reading aims to extract information from a written text, since it is a receptive type of oral activity.

\section{Main part}

Methodists approach the definition of reading types in different ways. Since methodological science requires the ultimate specification of learning objects, in the history of the methodology there are various attempts to classify reading types for different purposes [1; 346-347]. Several types of readings are distinguished: classroom and extracurricular / homework, with or without a dictionary, independent or nonindependent, prepared - unprepared (according to the conditions of their implementation), translated and uninterrupted (according to the psychological characteristics of perception), detailed and cursory, extensive - intensive (according to the volume of what is read), excursion and discursive (different degrees of understanding), professional reading, analytical and synthetic (according to the psychological characteristics of perception), as well as critical, referential andinformative. The most relevant and generally recognized typein professional language training is the classification depending on the purpose of reading.

According to the classification of S.K. Folomkina [2], four reading types are distinguisheddependingon goals: reading forlearning, reading for introduction, skim and scan reading, and reading for search.It is enough to limit non-philologists majors to these four types of professional reading, because they fully satisfy the needs of specialists in the process of acquiring the necessary information from the educational text.

Introductory reading is a cognitive reading, in which the entire text of an article, story, or a book becomes the subject of the student's attention without the intention of receiving certain information.

Reading for search is aimed at finding specific information in the text - definitions, formulations, digital or other data, about which the student already knows from other sources (educational material on their major, read in the language of education), and is contained in this book, article.

Skim and scan reading involves getting a general idea of the material. Its purpose is to get the general idea of the topic and the range of issues discussed in the text. To teach skim and scan reading, it is necessary to select a number of thematically related text materials and create skim and scan case situations. Study as-

\footnotetext{
*Corresponding author's e-mail: vipbekmasheva@mail.ru
} 
signments should be aimed at forming skills and abilities to navigate in the logical-semantic structure of the text, the ability to select and use material of the text.

Reading for learning provides the most complete and accurate understanding of all information contained in the text and its critical understanding. Most importantly, student gains self-study skills to understand information in the text. The task of the reading for learning is also formation of the student's ability to independently overcome difficulties in understanding a foreign language text.

These four types of reading: introductory, searching, skimming and scanning, and studying provide solution to almost all the most frequent problems that arise in relevance to communicative, cognitive and aesthetic needs when person addresses texts.

The peculiarity of pedagogical communication in teaching reading skillsis in its interaction: during teaching reading skills, contact is carried out through written and oral pre-text tasks, various kinds of instructions, directions, and comments on the text. The teacher compiles these assignments, instructions, tests and ways for self-control for a specific methodological purpose. With their help, the teacher controls understanding of the text by students, gives an assessment, interprets its content and meaning properly.

Pretext assignments usually formulate background knowledge. This is especially important for reading professionally oriented texts. The task emphasizes the authenticity of the material. For example, based on the title of the text, guess its content. Another task - students select a background terminological foundation based on the interpretation of the same title. In addition, depending on the language level of students, pretext tasks can targetelimination of language difficulties or work with lexical and grammatical structures. For instance:

- Read the text. Pay attention to the tense of the predicate verbs. In which parts of the text is past tense verbs used, and in which parts - present? What is the reason for this?

- Write out verbs from the text with the meaning of speech and thought. Write down all the grammatical forms of these verbs.

- Make sentences with words and phrases: dispersion medium, colloidal system, thermal conductivity, hydrophilic substances, and chemical reactions.

- Rewrite sentences with direct speech. Explain the setting of punctuation marks. Convert direct speech into indirect speech, replacing these constructions with complex sentences with explanatory clauses.

- Indicate homogeneous parts of the sentence, determine their grammatical forms.

However, this does not mean that pedagogical activity in teaching reading skills predominantly excludes oral communication between students and the teacher. It is known that teaching to read is combined with teaching to speak based on the text, therefore, pedagogical communication in the process of teaching reading skills should include forms applicableto both reading skills and speaking skills. Pedagogical communication in teaching reading skills can be defined both indirectly (through the text) and directly communicative interaction between the teacher and the student. As a result, formation, development and improvement of reading skills and abilities occurs, management of their mastery, control and self-control of their formation, as well as educational impact on the student is carried out. The success of language training can be ensured only under the condition of the correct organization of pedagogical communication in the classroom [3].

Consideration of reading as one of the forms of professional communication imposes special requirements on the selection of texts that provide information content, expressiveness of the main idea of the text, its concept, the understanding of which is the goal of professionally significant reading; teaching methods that promote deeper understanding and assimilation. Understanding of the text is realized through component analysis. The following steps could be taken:

\section{Read the text.}

2. Divide it into micro-themes and characterize their type.

3. Track how micro themes are related.

4. Determine the main theme of the text.

5. Title the text.

At the initial levels of language training, reading texts as a taskfocuses on two types - introductory reading and reading for learning. The ability to work with such reading types is necessary for a specialist for his professional work. At this stage of teaching reading skills at a university, the text should not contain a lot of new, unfamiliar information in the content. At this stage, the student's task is to be able to learn what is familiar, but stated in another language. At this stage of education, not only the language and speech competencies of reading are formed, but also the skills associated with understanding the content of the text. These 
skills provide depth of understanding, hence the communicative competence of reading. To understand the text, students need the help of a teacher, expressed by questions:
1. What is the goal of the author?
2. What topic does the author raise in the text? Determine the theme and message of the text.
3. To whom is the text addressed?
4. What type of speech is text?

With the transition to the subsequent stages of teaching reading skills in a foreign language educational or scientific texts, which are more close to original native language, the volume of new meaningful information on the major discipline gradually increases. The main task of the final stage of teaching reading skills is to teach students to read literature with a variable purpose (introduction, search for information, skim/scam and detailed reading), that is, to use all kinds of combinations of types of reading. In addition, students are supposed to perform various types of work with literature in theirmajor - translations, reports, abstracts, annotations, etc. These types of work should be accompaniedalong withsupporting comments of the teacher. For instance:

When writing an essay/paper, do not rely too much on quoting. Remember that the essay is much more an independent work than a synopsis. Use different methods of reporting someone else's speech. For example, in his article the author writes about...; questions are considered...; work consists of...; the author discusses...; the author takes the point of view...; the conclusions made by the author....

For successful and effective implementation of a reading course, it is necessary to resolve the issue of the selection and organization of text material. Along with the general features typicalto any text, the educational text has a number of distinctive features that are due to the specifics of educational communication.

The main requirements for the texts used in the educational process are:

- the cognitive value of texts and the scientific nature of the content;

- the relevance of the content of the texts to the interests of students. Often, readers' interests are broad, therefore, in the educational process various texts borrowed from popular science, scientific or scientifictechnical literatureshould be used. When choosing a text for a particular type of reading, they are guided by two main criteria: a) its logical-semantic structure and information abundancy and b) its linguistic complexity.

When selecting material for the student and introductory types of reading, it is important to take into account the number of unfamiliar (new) words in the text. If the text contains up to twenty-five percent of unfamiliar meaningful words, then it can be used only for introductory reading. So, if there are more unfamiliar words, then it is only suitable as reading for learning. To ensure presence of practical experiencewhile applying reading forlearning, introductory reading, as well as skim/scan and searching, it is necessary to include in educational materials special texts reflecting different genres of a literature (abstracts, patents, etc.), as well as various types of journal articles (article-description, article-reasoning). At the final stage of training, it is recommended to use literature on an original language according to area of study.

It is also advisable to use special teaching aids for abstracting, annotating, taking notes, and reviewing.

The next stage is the development of exercises for acquiring skills related to mastering the skill of recognizing and decoding text while reading. The task of the exercises on mastering language means is to teach students to recognize the words under study in any context, that is, to distinguish between lexical and semantic variants. After the selection of word-formation, lexical and grammatical structures necessary for mastering the studied texts, their training begins. It is necessary to remember about the «dialogical» form of exercises, when new vocabulary is intorduced. It is also appropriate to train not only the terminological and general scientific vocabulary, but also the official vocabulary of the scientific language and the modal-evaluative vocabulary of the oral form of communication.It should be emphasized that the work on the formation of basic knowledge should also take place, especially at the initial stage, in accordancewith clear algorithms with dubbing of all the material. It is also recommendedto perform exercises to establish semantic relationships between words, sentences and paragraphs. For this, grammatical analysis is carried out in order to recognize various forms by their external features and determine the functions of these forms in a specific sentence. Academic, scientificand technical texts differ from popular science and journalistic texts both in language and structure. They lack a plot and emotional coloring, but there are a large number of terms. When reading such texts, it is difficult for a student to use the techniques of contextual guesswork, since the text is built around facts, theories, principles, processes, or other abstract concepts that even in their native language require significant mental work. These texts are classified as authentic. 
Reading an authentic professional text assumes that a student has the ability to extract necessary professional information from the proposed material for further use in his/her activities. Work on the text itself involves the contextualization of its communicative fragments at the sentence level (selective translation of communicative fragments with new special vocabulary, choosing the right or wrong statement, text exercises based on multiple choice such as «complete», «fill in», «suggest synonyms (antonyms)», as well as conversations, etc.).

Today, the concept of «authenticity» is considered as a characteristic of the educational process, which is reflected in the work of E.V. Nosonovich. He defines methodological authenticity as «the creation for educational purposes of materials, tasks and situations that are as close as possible to natural. Firstly, methodologically authentic text correspondsto thr speech norms accepted by native speakers, and, secondly, specific communication tasks «[4;12]. The same E.V. Nosonovich says that texts are considered authentic if they were not specially created for educational purposes, but were originally intended by the author for native speakers and performing their real function for non-educational purposes. That is, an authentic text is a product of real communication [6;139]. The same opinion is shared by S.K. Folomkina, who accepts «authenticity» as originality, borrowing from genuine sources created by native speakers and not pursuing educational goals. The key characteristic of an authentic text is its complexity $[2,68]$. The authenticity of the text should be reflected both in compositional and linguistic terms. This requires the presence of such attributes as integrity, logical coherence, features of the sentence formationexpressed in the scientific and technical styles in general.

Authentic texts must be adapted depending on the language level of the students. Adapted texts are actually the same authentic texts, but for methodological purposes small changes such as simplification and the strengthening of certain characteristics of the text is made. The adapted texts are of particular importance at the initial levels of language training. Working with adapted professionally-oriented texts is based on completing a set of tasks. For instance:

1. Explanation of the lexical meaning of the following words according to the dictionary of S.I. Ozhegov:...

2. Matching of synonyms for words:...

3. Reading the text, highlighting the main information.

4. Question-answer conversation.

5. Finding constructions with temporal and abstract meaning in the text.

6. Outlining thesis and writing abstracts.

The final post-text stage involves the transformation of texts in various ways in order to present new text information to the student. Depending on the language level, this can be retelling, formulating questions, taking notes, drawing up a plan, testifying, annotating. To introduce and consolidate lexical and grammatical material, to develop skills and abilities, modern didactic principles of visualization, audio and multimedia, video equipment should be widely used. They help to simulate case studies in which language learning takes place immersing in the cultural and professional environment of its native speakers.

Post-text tasks can be divided into two groups. The first group includes tasks, the implementation of which reveals understanding of the reading, while the fulfillment of tasks of the second group involves work with oral and written speech. Control ofreading is performed by the following tasks:

1. Find and read the sentences that answer these questions...

2. Find and read the passage where this statement is confirmed (refuted)...

3. Find sentences in the text that have the main semantic idea.

4. Answer the questions - «yes» or «no».

5. Title the text.

6. Make a question plan for the text.

7. Formulate the main theses of the text.

8. Determine which of these statements do not match to the content of the second paragraph.

9. Answer the questions.

10. Arrange these theses in the sequence corresponding to the content of the text.

The purpose of the exercises used at the post-text stage is the formation of probabilistic language and semantic forecasting skills. Possible areas of work for the teacher and students - lexical and grammatical analysis of the text (comparison of lexical units; selection of semantically close (opposite) words, their compatibility, semantic connections and relationships); semantic analysis of the heading of a text; decomposition of a text into structural, syntactic and semantic parts; consideration of various ways of expressing subject- 
object relations in the Russian sentence; analysis of various types of complex sentences; study of means of inter-sentence communication, etc. When determining the degree of complexity and coherencein the use of exercises, the following should be considered:

- the content and volume of the lexical-grammatical and syntactic material should be sufficient for a particular stage of language learning;

- the sequence of using the material in the exercises should take into account the growth of linguistic and operational difficulties;

- the number of exercises should be sufficient to automate actions and operations that ensure transition from conscious proficiency of linguistic material to its unconscious use in the speech.

It is important to organize the activities of students in the process of performing the exercises in such a way that the consolidation of the obtained lexical, grammatical and syntactic knowledge is sensible. Therefore, the material offered to students should contain important and useful information for them. Methodologically well-organized work on the content of the text will help readers realize the positive role of the target language system in satisfying their communicative and cognitive needs and create conditions for the formation of the necessary oralabilities and language skills.

When teaching introductory and learning types of reading, there are usually used tasks that reflect real situations of professional reading of a specialist, for example, writing an abstract to an article; reading part of the article / text of an interest; accurate translation of a sample / part of an article / text. Selection of texts for solving the proposed problem / task can be recommended as an assignment.

For the development of skim and scan reading, proper situations are created. Students are given opportunity to choose one of several proposed texts of the workbook or the journal. At the same time, it is necessary that the student justifies his choice, explains the reasons why he rejected other texts. To do this, he/she looks through the proposed texts using skim and scan reading.

Reading for search exists as an independent type of reading and it is important for future professional work. Exercises related to the search for specific information are done in the lesson. These skills are necessary for students to search and select literature for an essay, report, for writing an annotation for an article or a report.

Te result of teaching reading skills in a professional foreign language appears through the control of understandingof a reading material. When determining the level of readingskills in the target language, the assessment is carried out according to the results of the tasks for search, introductory reading or reading for learning at the intermediate and upper stages of training.

Self-reading assignments are creative and serve as practice in various types of reading [5]. To develop students' necessary skills in one or another form of reading, it is necessary to connect independent reading with complex content. For example, the preliminary selection of texts for reading and subsequent reading can be oriented towards the implementation of state programs such as «Rukhani zhangyru» [6]. This kind of reading is associated not only with the identification of professional texts, but also with the spiritual and moral education of students.

\section{Research results}

So, in the professional language training to form the necessary professional competencies of intercultural communication, it is important to teach students reading skills based on literature on their major profession, ensuring the ability to generate and adequately interpret information in the target language. For a future specialist to be able to timely updatethe latest information in the areaof his profession, it is necessary to pay special attention to the development of exactly those types of readingskills that correspond to his needs namely reading for search, skim and scan, introductory reading and reading forlearning.

\section{References}

1 Азимов Э.Г. Новый словарь методических терминов и понятий / Э.Г. Азимов, А.Н. Щукин. — М.: Изд-во «ИКАР», 2009. - $448 \mathrm{c}$.

2 Фоломкина С.К. Обучение чтению на иностранном языке в неязыковом вузе: учеб. пос. для вузов / С.К. Фоломкина. — М.: Высш. шк., 1987. — 200 с.

3 Серова Т.С. Психологические и лингводидактические аспекты обучения профессионально-ориентированному иноязычному чтению в вузе / Т.С. Серова. - Свердловск: Урал. гос. ун-т, 1988. - 227 с. 
4 Носович Е.В. Параметры аутентичного учебного текста / Е.В. Носович, Р.П. Мильруд // Иностранные языки в школе. - 1999. - № 1. - С. 11-21.

5 Корнилова Л.И. Из практики организации аудиторной и внеаудиторной работы при обучении чтению на иностранном языке в неязыковом вузе / Л.И. Корнилова // Профессиональная ориентированность обучения иностранному языку в условиях неязыкового вуза. - М.: Наука, 1987. - 152 с.

6 Жилбаев Ж.О. Ценности модернизации общественного сознания (духовного возрождения) в контексте когнитивной педагогики / Ж.О. Жилбаев, Л.С. Сырымбетова, Л.М. Муратова // Вестн. Караганд. ун-та. Сер. Педагогика. - 2019. - № 2. - С. 88-93.

\title{
А.Н. Бекмашева, М.Қ. Ажгалиев \\ Оқылым кәсіби бағытталған тілдік дайындықтағы сөйлеу әрекетінің түрі ретінде
}

\begin{abstract}
Мақалада кәсіби бағытталған тілдік дайындықтың өзекті мәселелері талданған. Оқылымды сөйлеу әрекетінің түрі ретінде оқытуға ерекше көңіл бөлінген. Оқушылардың тілдік дайындық деңгейіндегі айырмашылықтарды ескере отырып, оқудың әртүрлі түрлерін оқыту мәселелері зерттелген. Оқылым ауызша сөйлеу қарым-қатынасының дағдылары мен дағдыларын дамытуға ықпал ететін сөйлеу әрекетінің бір түрі ретінде қарастырылған. Сөйлеу әрекетінің бұл түрі оқытудың мазмұны мен негізгі принциптері, сондай-ақ оқыту реттілігі бойынша оқыту құралы ретінде сипатталған. Көптеген ғалымдар оқылым түрлерін жіктеуге негізделген кәсіби бағытталған оқыту негізінде тапсырмалардың түрлері мен сөйлеу құзыреттілігін қалыптастыру жолдарын ұсынады. Шет тіліндегі мәтіннің қиындықтарын жеңудің жолдары ұсынылған. Мақалада оқылымның әртүрлі түрлерін оқытудың негізгі принциптері көрсетілген.
\end{abstract}

Кілт сөздер: оқылым, сөйлеу әрекетінің түрі, кәсіби бағытталған тілдік дайындық, оқу түрлері, аутентикалық мәтін.

\section{А.Н. Бекмашева, М.К. Ажгалиев \\ Чтение как вид речевой деятельности В профессионально-ориентированной языковой подготовке}

\begin{abstract}
В статье проанализированы актуальные вопросы профессионально-ориентированной языковой подготовки. Особое внимание уделено обучению чтению как виду речевой деятельности. Поставлены проблемы обучения разным видам чтения с учетом различий в уровне языковой подготовки обучающихся. Чтение рассмотрено как вид речевой деятельности, способствующий развитию навыков и умений устной речевой коммуникации. Данный вид речевой деятельности также характеризуется как средство обучения по содержанию и основным принципам обучения, а также последовательности обучения. Авторы на основе классификаций видов чтения, выдвигаемых большинством учёных, предлагают свои типы заданий и пути формирования речевой компетенции на основе обучения профессиональноориентированному чтению. Предложены пути преодоления трудностей иноязычного текста. В статье выдвинуты основные принципы обучения различным видам чтения.
\end{abstract}

Ключевые слова: чтение, речевой вид деятельности, профессионально-ориентированная языковая подготовка, виды чтения, аутентичный текст.

\section{References}

1 Azimov, E.G. \& Shchukin, A.N. (2009). Novyi slovar metodicheskikh terminov i poniatii [New dictionary of methodical terms and concepts]. Moscow: Izdatelstvo «IKAR» [in Russian].

2 Folomkina, S.K. (1987). Obuchenie chteniiu na inostrannom yazyke v neiazykovom vuze [Teaching to read in a foreign language in a non-linguistic university]. Moscow: Vysshaiia shkola [in Russian].

3 Serova, T.S. (1988). Psiholohicheskie i linhvodidakticheskie aspekty obucheniia professionalno-orientirovannomu inoiazychnomu chteniiu $v$ vuze [Psychological and linguo-didactic aspects of teaching professionally oriented foreign language reading at a university]. Sverdlovsk: Uralskii hosudarstvennyi universitet [in Russian].

4 Nosovich, E.V. \& Milrud, R.P. (1999). Parametry autentichnoho uchebnoho teksta [Parameters of authentic educational text]. Inostrannye yazyki v shkole - Foreign languages at school, 1, 11-21 [in Russian].

5 Kornilova, L.I. (1987). Iz praktiki orhanizatsii auditornoi i vneauditornoi raboty pri obuchenii chteniiu na inostrannom yazyke $\mathrm{v}$ neiazykovom vuze [From the practice of organizing classroom and extracurricular work in teaching reading skills in a foreign language in a non-linguistic university]. Professionalnaia orientirovannost obucheniia inostrannomu yazyku $v$ usloviiakh 
nezhazykovoho vuza - Professional orientation of teaching a foreign language in a non-linguistic university. Moscow: Nauka [in Russian].

6 Zhilbaev, Zh.O., Syrymbetova, L.S., \& Muratova, L.M. (2019). Tsennosti modernizatsii obshchestvennoho soznaniia (duhovnoho vozrozhdeniia) $\mathrm{v}$ kontekste kohnitivnoi pedahohiki [Values of modernization of public consciousness (spiritual revival) in the context of cognitive pedagogy]. Vestnik Karahandinskoho universiteta. Seriia Pedahohika - Bulletin of Karaganda University. Series Pedagogy, 2, 88-93 [in Russian]. 